OPEN ACCESS

Edited by:

Toshinori Nakayama,

Chiba University, Japan

Reviewed by:

Craig Michael Walsh,

University of California, Irvine,

United States

Akihiko Murata,

Tottori University, Japan

${ }^{*}$ Correspondence:

Jun Dong

dong@drfz.de

tPresent address

Weijie Du

BIH Center for Regenerative

Therapies, Berlin, Germany

Daniel Lenz,

Miltenyi Biotec $\mathrm{GmbH}$, Bergisch

Gladbach, Germany

$\neq$ These authors have contributed equally to this work

Specialty section:

This article was submitted to

Immunological Memory,

a section of the journal

Frontiers in Immunology

Received: 30 October 2020 Accepted: 23 February 2021

Published: 22 March 2021

Citation:

Du W, Lenz D, Köhler R, Zhang E,

Cendon C, Li J, Massoud M,

Wachtlin J, Bodo J, Hauser AE, Radbruch A and Dong J (2021) Rapid Isolation of Functional ex vivo Human

Skin Tissue-Resident Memory T Lymphocytes.

Front. Immunol. 12:624013.

doi: 10.3389/fimmu.2021.624013

\section{Rapid Isolation of Functional ex vivo Human Skin Tissue-Resident Memory T Lymphocytes}

\author{
Weijie $\mathrm{Du}^{1 \dagger}$, Daniel Lenz ${ }^{1 \neq \neq}$, Ralf Köhler ${ }^{2 \neq}$, Erping Zhang ${ }^{3}$, Carla Cendon ${ }^{1}$, Jinchan $\mathrm{Li}^{1}$, \\ Mona Massoud ${ }^{1}$, Joachim Wachtlin ${ }^{3,4}$, Juliane Bodo ${ }^{5}$, Anja E. Hauser ${ }^{2,6}$, \\ Andreas Radbruch ${ }^{1}$ and Jun Dong ${ }^{1 *}$

\footnotetext{
${ }^{1}$ Cell Biology, Deutsches Rheuma-Forschungszentrum Berlin, Institute of the Leibniz Association, Berlin, Germany, ${ }^{2}$ Central Lab for Microscopy, Deutsches Rheuma-Forschungszentrum Berlin, Institute of the Leibniz Association, Berlin, Germany,

${ }^{3}$ Sankt Gertrauden Krankenhaus, Berlin, Germany, ${ }^{4}$ Medizinische Hochschule Brandenburg, Neurrupin, Germany,

${ }^{5}$ Plastische und Ästhetische Chirurgie, Berlin, Germany, ${ }^{6}$ Immune Dynamics, Rheumatology and Clinical Immunology,

Charité Universitätsmedizin Berlin, Berlin, Germany
}

Studies in animal models have shown that skin tissue-resident memory $T$ ( $T_{\text {RM }}$ ) cells provide enhanced and immediate effector function at the site of infection. However, analyses of skin $T_{R M}$ cells in humans have been hindered by the lack of an optimized isolation protocol. Here, we present a combinatorial strategy-the 6-h collagenase IV digestion and gentle tissue dissociation - for rapid and efficient isolation of skin $T_{\text {RM }}$ cells with skin tissue-specific immune features. In comparison with paired blood circulating memory $T$ cells, these ex vivo isolated skin $T$ cells express typical $T_{R M}$ cell markers and display higher polyfunctional properties. Moreover, these isolated cells can also be assessed for longer periods of time in ex vivo cultures. Thus, the optimized isolation protocol provides a valuable tool for further understanding of human skin $T_{R M}$ cells, especially for direct comparison with peripheral blood $T$ cells at the same sample collection time.

Keywords: human skin, tissue-resident memory T cells, yield, epitope, collagenase IV, gentle tissue dissociation, cell isolation

\section{INTRODUCTION}

Recent research has provided compelling evidence that, in addition to circulating memory $\mathrm{T}$ cells, there are also significant non-circulating tissue-resident memory $\mathrm{T}\left(\mathrm{T}_{\mathrm{RM}}\right)$ cells residing in many tissues, such as in the skin, lungs, gut, liver (1-5), and bone marrow (6-10). Most but not all these $\mathrm{T}_{\mathrm{RM}}$ cells express CD69 $(7,11-13)$, which probably contributes to their retention in tissues (1416). Similarly, most $T_{R M}$ cells do not express the chemokine receptor CCR7 $(3,7)$. Animal models showed that skin $\mathrm{T}_{\mathrm{RM}}$ cells mediate first lines of defense against previously encountered pathogens $(1,2,17,18)$. Approximately $2 \times 10 \mathrm{e} 10$ resident $\mathrm{T}$ cells have been estimated to be present in normal human skin. This number doubles that of circulating $\mathrm{T}$ cells in the peripheral blood (19). However, present understanding of human skin $\mathrm{T}_{\mathrm{RM}}$ cells has been challenged by the lack of an optimized isolation protocol. In this regard, various approaches have been utilized to isolate skin $\mathrm{T}_{\mathrm{RM}}$ cells, such as EDTA isolation (19), collagenase P (20), collagenase IV digestion $(19,21)$, and skin explants (19). Nevertheless, these methods either suffer from low yield or require long-term in vitro culture periods. 
To establish an optimized protocol for rapid and efficient isolation of skin $\mathrm{T}_{\mathrm{RM}}$ cells, we have evaluated six different protocols in terms of the preservation of epitopes of interest, cell viability, and yield. Among these six approaches, the modified collagenase IV (M.CoIV) protocol, i.e., the combination of 6-h collagenase IV digestion and gentle tissue dissociation, outperformed other protocols and resulted in the highest viable cell number while robustly preserving critical surface marker expressions (such as CD4, CD8, and CD69). Importantly, the M.CoIV isolation procedure does not induce skin TRM cell activation and proliferation. Cytokine profiles of isolated skin memory $\mathrm{T}$ cells stimulated by SEB and anti-CD3/CD28 revealed functional capacities, to which the successfully isolated various types of antigen-presenting cells (APCs), such as dermal dendritic cells (DDCs) and Langerhans cells (LCs), may contribute.

\section{RESULTS}

\section{Characterization of Human Skin T Cells in situ}

To characterize the human skin $\mathrm{T}$ cells in situ, we performed immunofluorescence histology on $6 \mu \mathrm{m}$ sections of eyelid and abdominal skin samples from healthy donors (Supplementary Table 1). Sections without antibody staining (Supplementary Figure 1A) or only with secondary antibody staining (Supplementary Figure 1B) were used as background controls. As shown in a large tile scan and the regions of interest (ROI) 1 and 2 in Figure 1A, CD8 ${ }^{+} \mathrm{T}$ cells localized in both the epidermis and dermis layers, while $\mathrm{CD}^{+} \mathrm{T}$ cells were mainly detected in the dermis and clustered around the hair follicles, with only few $\mathrm{CD} 4^{+} \mathrm{T}$ cells detected in the epidermis. Most $\mathrm{CD}^{+}{ }^{+} \mathrm{T}$ cells, $\left(\mathrm{CD} 4^{+}\right.$and $\left.\mathrm{CD} 8^{+}\right)$, expressed CD69, indicating a tissue residency status of these $\mathrm{T}$ cells (Figure 1A). Skin $\mathrm{CD}^{+} \mathrm{T}$ cells expressed the skin homing markers, such as CLA (cutaneous lymphocyte-associated antigen) (Figure 1B) and did not express the proliferation marker Ki-67 (Figure 1C) or lymph node homing markers, such as CCR7 (Figure 1D). Quantitative analysis of immune cells present in the skin sections (Supplementary Figure 2) showed that, $14.4 \%( \pm 10.8)$ of skin cells were $\mathrm{CD}^{+} \mathrm{T}$ cells and among them $68.97 \%( \pm 8.06)$ and $24.56 \%( \pm 13.81)$ were $\mathrm{CD}^{+}$and $\mathrm{CD}^{+} \mathrm{T}$ cells, respectively, resulting in the ratio of $\mathrm{CD}^{+}$to $\mathrm{CD}^{+} \mathrm{T}$ cells of $\sim 3: 1$ (Figure 1E). Additionally, while more than $65 \%$ of $\mathrm{CD}^{+} \mathrm{T}$ cells co-expressed $\mathrm{CD} 69$ and $75 \%$ co-expressed CLA, there were only $16 \%$ of $\mathrm{CD}^{+} \mathrm{T}$ cells co-expressing CCR7 (Figure 1E). The variation in frequencies especially of $\mathrm{CD}^{+} \mathrm{T}$ cells may reflect their uneven distribution in the skin. To identify the spatial distribution between $\mathrm{T}$ cells and dendritic cells, CD1a was concomitantly used with CD3 in the immunofluorescence staining. We observed that $\mathrm{CD} \mathrm{a}^{+}$dendritic cells mainly resided in the epidermis layer and were close to $\mathrm{CD} 3^{+} \mathrm{T}$ cells (Figure 1F). Similarly, $\mathrm{T}$ cells expressing CD69 were also identified in the dermis of abdominal skin samples (Supplementary Figure 3A), although a strong autofluorescence signal in the FITC channel was detected
(Supplementary Figure 3B), likely due to the intensive collagen fiber structures present in the abdominal skin. Together, these results suggest that normal human skin $\mathrm{T}$ cells are resting and qualify as $\mathrm{T}_{\mathrm{RM}}$ cells.

\section{The Modified Collagenase IV Protocol Best Preserves Cell Surface Markers of Interest With High Cell Viability and Yield}

To optimize the protocol for isolating human skin $\mathrm{T}$ cells, skin samples were minced and subjected to six reasonable protocols, each including a 3-, 6-, or 12-h enzymatic digestion (Figure 2A). These protocols are: combination of 1) a 12-hour collagenase IV digestion, i.e. modified collagenase IV digestion (M.CoIV)_12h; 2) M.CoIV_6h; 3) whole skin dissociation plus enzyme $\mathrm{P}$ digestion (WSD+EnzP_12h); 4) WSD-EnzP_12h (without enzyme $\mathrm{P}$ digestion); 5) $\mathrm{CoP}+\mathrm{CoIV} \_12 \mathrm{~h}$; or 6) cocktail of enzymes (collagenase I, elastase, hyaluronidase, and trypsin inhibitor) (Cocktail_3h), with gentle tissue dissociation (Supplementary Table 2). Cell isolated using these protocols were compared for expressions of CD45, CD3, CD4, CD8, CD69, CLA, and CCR7 among viable cells by flow cytometry. Notably, the modified collagenase IV (either 6- and 12-h digestion time) and cocktail protocols were the best to preserve the epitopes of antigens, such as CD4 (Figure 2B), CD8 (Figure 2C), and CD69 (Figure 2D). In terms of cell viability, significantly higher percentages of viable cells were isolated when using the M.CoIV_12 h and M.CoIV_6h protocols $(42.30 \pm 5.01 \%$ and $42.36 \% \pm 3.31 \%$, respectively) than the cocktail_3 $\mathrm{h}$ protocol $(26.33 \pm 5.14 \%)$ (Figure 2E). In terms of viable $\mathrm{T}$ cell number, the M.CoIV_6h protocol isolates more cells $(28.73 \pm 7.68$ $\times 10^{4}$ live $\mathrm{T}$ cells per $\mathrm{cm}^{2}$ ) than the M.CoIV_12 $\mathrm{h}$ and cocktail_3h protocols $\left(19.29 \pm 3.25 \times 10^{4}\right.$ and $10.81 \pm 5.29$ $\times 10^{4}$ live $\mathrm{T}$ cells per $\mathrm{cm}^{2}$, respectively) (Figure $2 \mathrm{~F}$ ). Thus, the M.CoIV_6h protocol significantly outperformed other isolation protocols, representing an optimized protocol for isolating skin T cells.

\section{Characterization of ex vivo Skin T Cells}

Using the optimized isolation protocol M.CoIV_6h, we next characterized cells isolated from 12 (including 8 paired) skin samples in comparison with peripheral blood samples of 50 - to 80 -year-old individuals by flow cytometry (Supplementary Figure 4). Compared to blood, skin contained significantly lower frequencies of CD45 expressing lymphocytes (72 vs. 20\%) (Figure 3A). However, among CD $45^{+}$lymphocytes, frequencies of $\mathrm{CD}^{+}{ }^{+} \mathrm{T}$ cells as well as $\mathrm{CD} 4^{+}$and $\mathrm{CD} 8^{+} \mathrm{T}$ cells were comparable between skin and blood, resulting in the ratio of $\mathrm{CD} 4^{+}$to $\mathrm{CD} 8^{+}$T cells of 3:1 (Figure 3B), in line with that of skin $\mathrm{T}$ cells in situ (Figure 1E). The majority of skin T cells expressed CD45RO (87.93\%), indicating a memory phenotype, whereas only approximately half of blood $\mathrm{T}$ cells (50.90\%) expressed CD45RO (Figure 3C). Moreover, ex vivo skin memory $\mathrm{T}$ cells expressed the tissue resident markers such as CD69 (81.86\%) and skin homing molecule CLA (75.08\%) but rarely tissue egress markers, such as CCR7 (10.91\%), in contrast to blood T cells (57.37\%) (Figure 3D). Among $\mathrm{CD}^{+} \mathrm{T}$ cells, except for CCR7 

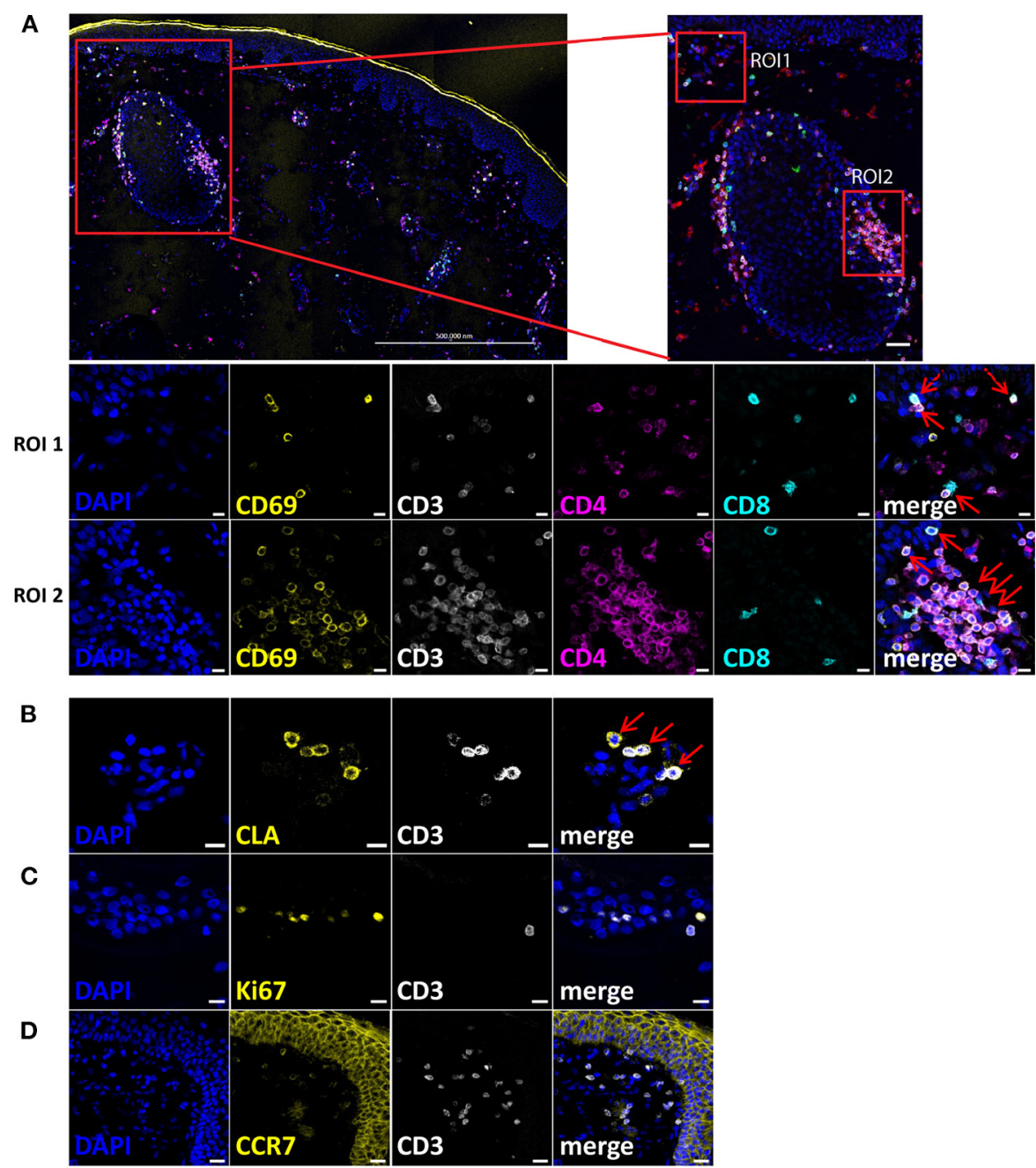

E
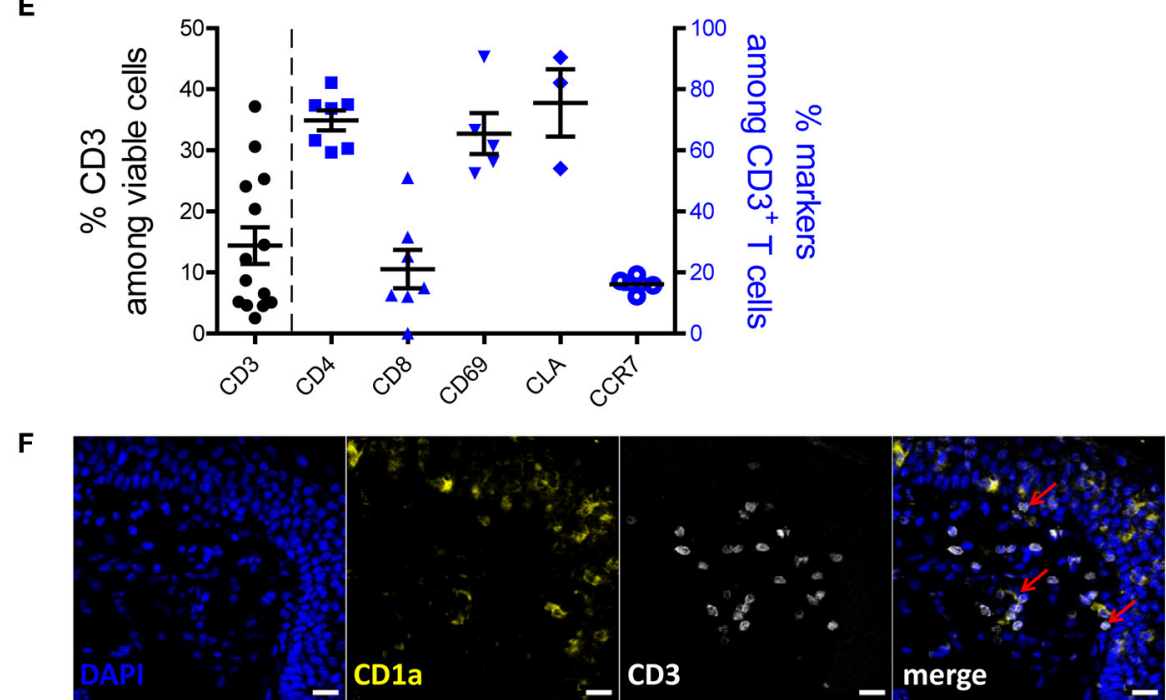

FIGURE 1 | Phenotypic characterization of human skin cells in situ. (A) A $3 \times 4$ tile scan image of skin section stained with DAPI (blue), CD69 (yellow), CD3 (white), CD4 (violet) and CD8 (turquoise). Region of interest (ROI) 1 is a representative image of the cells located in the epidermis and ROI2 is a representative image of the cells around a hair follicle in the dermis. (B-D,F) Skin sections were stained with DAPI (blue) and CD3 (white) as well as one of the following: CLA (B), Ki-67 (C), CCR7 
FIGURE 1 | (D) or CD1a (F). Scale bar: $500 \mu \mathrm{m}$ for (A) upper left, $20 \mu \mathrm{m}$ for (A) upper right, (D,F); $10 \mu \mathrm{m}$ for A-ROl1, A-ROI2, (B,C). Co-expression of $\mathrm{CD}^{+}{ }^{+} \mathrm{CD}^{+} / \mathrm{CD}^{+}$and $\mathrm{CD} 9^{+}$cells, and $\mathrm{CLA}^{+}$and $\mathrm{CD}^{+}$cells are indicated by red arrows. Representative image sets from three independent experiments are shown. Scale bar: $20 \mu \mathrm{m}$ for (A,D,F); $10 \mu \mathrm{m}$ for (A-C). (E) Frequencies of $\mathrm{CD} 3^{+} \mathrm{T}$ cells among total cells (left $\mathrm{y}$-axis) and frequencies of indicated subpopulations of $\mathrm{T}$ cells among $\mathrm{CD}^{+} \mathrm{T}$ cells (right $\mathrm{y}$-axis), according to image cell quantification $(n=3 ; 14$ fields).

A

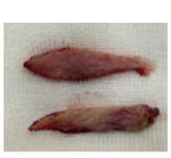

skin biopsies minced

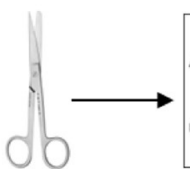

Digestion using different protocols
gentleMACS ${ }^{\mathrm{TM}}$ dissociation $\longrightarrow$ FACS analysis
B

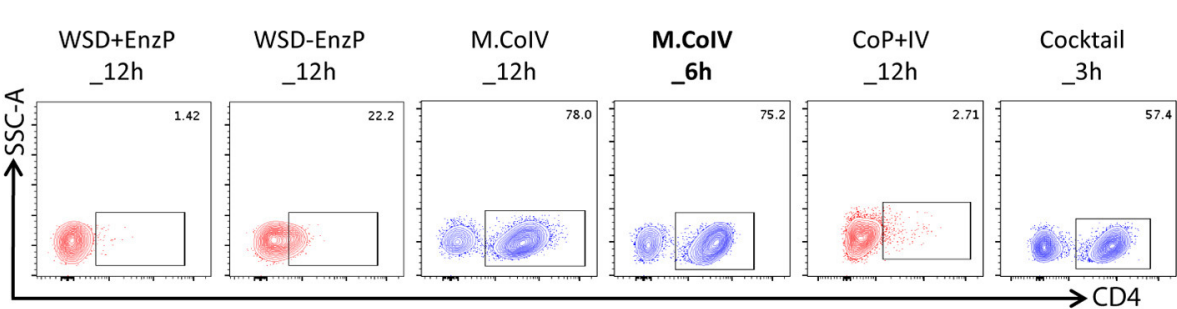

C

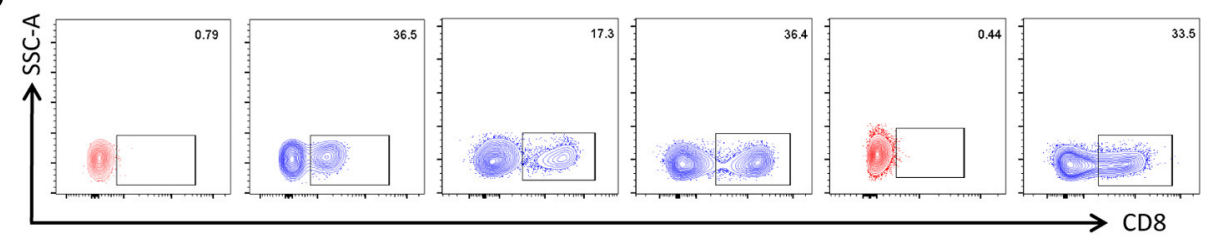

D
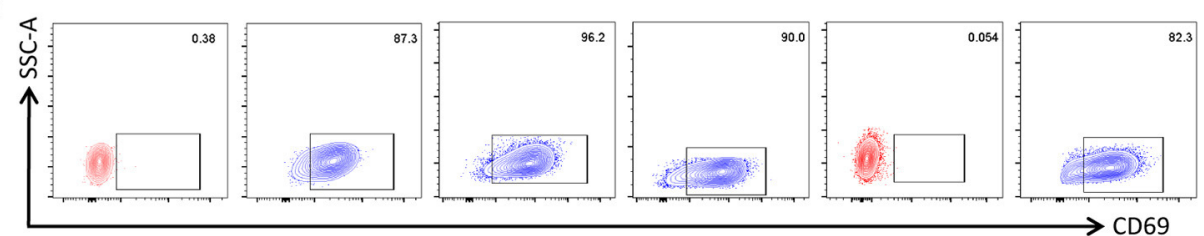

E $\%$ Cell Viability

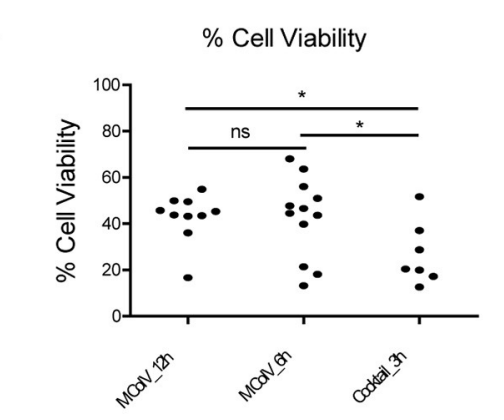

$\mathbf{F}$

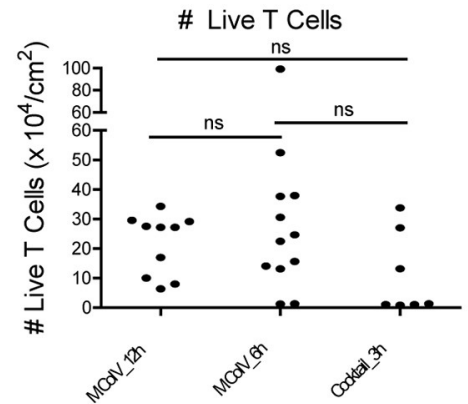

FIGURE 2 | Modified Collagenase IV protocol best preserves the epitopes of surface antigens with high cell viability and yield. (A) Schematic workflow of isolating cells from human skin samples. (B-D) Frequencies of $\mathrm{CD}^{+}$(B), $\mathrm{CD}^{+}$(C) and $\mathrm{CD} 69^{+}$(D) T cells among live $\mathrm{CD} 45^{+}$lymphocytes isolated by six different isolation protocols: (1) WSD+EnzP_12 h $(n=2)$, (2) WSD-EnzP_12 h $(n=2)$, (3) M.ColV_12 h $(n=12),(4)$ M.Colv_6 h $(n=12),(5)$ CoP+/-ColV_12h $(n=3)$, and (6) Cocktail_3h $(n=7)$. Each dot represents data obtained from one donor. Red dots showing cells isolated from skin samples using protocols that did not preserve the CD4 epitope. (E) Frequencies of viable cells and $\mathbf{F}$ ) the total number of viable T cells isolated by using the M.Colv_12 $\mathrm{h}$, M.Colv_6 $\mathrm{h}$ and cocktail_3 $\mathrm{h}$ isolation

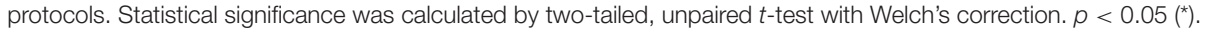


A

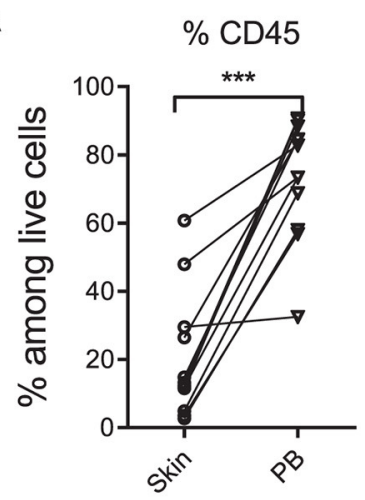

C

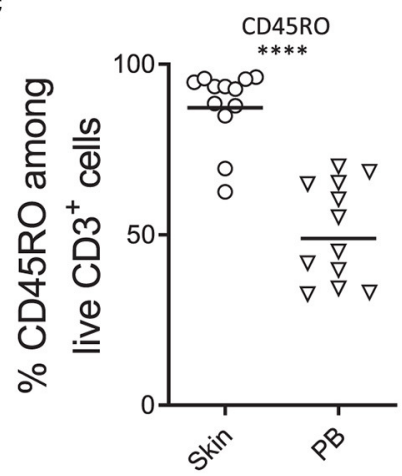

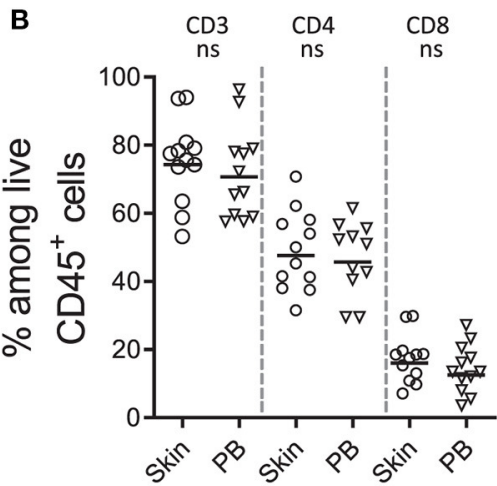

D

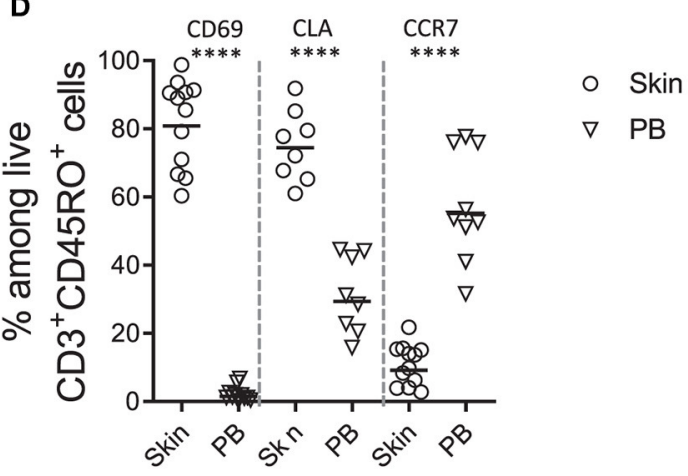

E

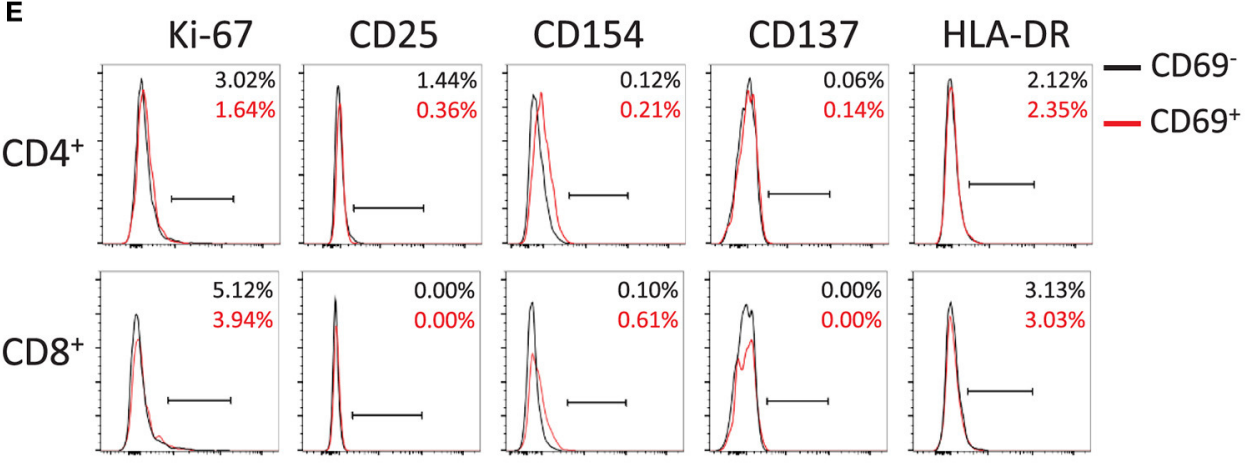

F

G

H
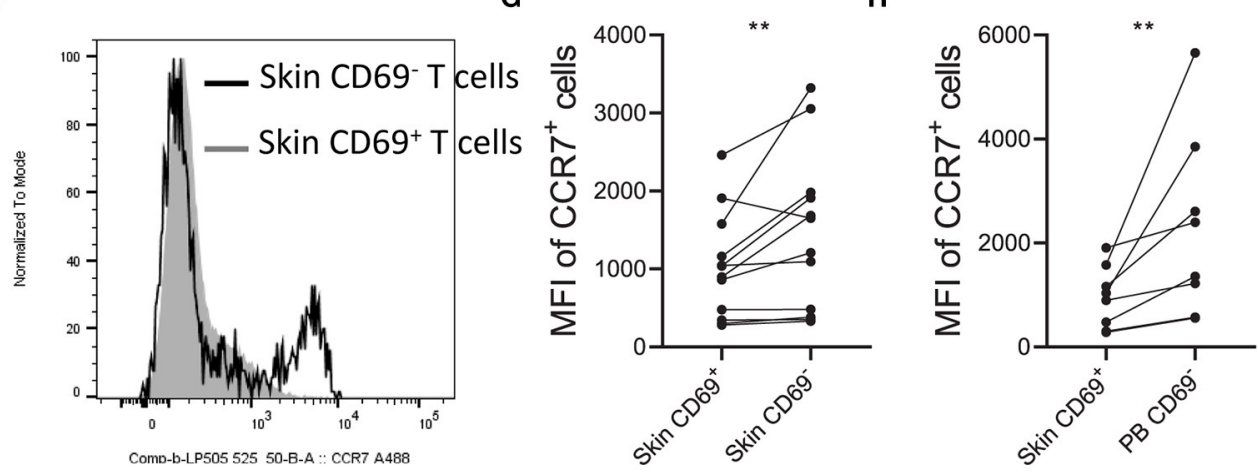

FIGURE 3 | Phenotypic characterization of skin T cells by flow cytometry. Frequencies of CD45 lymphocytes (A), CD3 ${ }^{+}, \mathrm{CD}^{+}$, and $\mathrm{CD} 8^{+} \mathrm{T}$ cells (B), CD45RO ${ }^{+}$

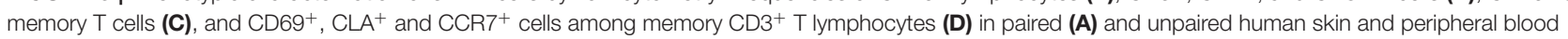
samples (B-D). (E) Overlay of histograms showing the percentages of cells expressing proliferating and putative activation markers (Ki-67, CD25, CD154, CD137 
FIGURE 3 | and HLA-DR) on CD69- (black line) and CD69 ${ }^{+}$(red line) memory CD4 ${ }^{+}$and $\mathrm{CD}^{+}{ }^{+}$T cells. Percentages are shown in the upper right of each plot. Representative data from more than 10 independent experiments are shown. (F) Overlay of histograms showing the expression of CCR7 on CD69+ (filled gray area) and CD69- (black line) skin T cells. Comparison of MFI (Mean Fluorescence Intensity) of CCR7 ${ }^{+}$cells between skin CD69+ and CD69- ${ }^{-}$cells (G) and between skin $\mathrm{CD}^{+}{ }^{+}$and blood CD69- T cells. In (A,G,H), Wilcoxon matched-pairs signed rank test, two-tailed; in (B-D), unpaired $T$-test with Welch's correction, two-tailed. ${ }^{\star \star * \star} P$ $<0.0001,{ }^{\star \star \star} P<0.001,{ }^{\star \star} P<0.005$, ns.

(16 vs. $10 \%$ ), the frequencies of these markers by ex vivo skin $\mathrm{CD}^{+} \mathrm{T}$ cells were similar to those by in situ skin $\mathrm{CD} 3^{+} \mathrm{T}$ cells (Figure 1E), suggesting that the M.CoIV_6h protocol enables isolation of proportional skin cells.

Studies have shown that steady-state $\mathrm{CD} 69^{+} \mathrm{T}_{\mathrm{RM}}$ cells from other tissues, such as the bone marrow (7), are resting in terms of activation. To test whether that would be also the case for normal skin $\mathrm{T}$ cells, we analyzed the expressions of proliferation marker Ki-67 and putative activation markers CD25, CD154, CD137 and HLA-DR on ex vivo skin T cell subsets isolated using the M.CoIV_6h isolation protocol. Similar to $\mathrm{CD} 9^{-}$memory $\mathrm{CD} 4^{+}$and $\mathrm{CD} 8^{+} \mathrm{T}$ cells, CD69 ${ }^{+}$ memory $\mathrm{CD}^{+}$and $\mathrm{CD}^{+} \mathrm{T}$ cells did not express these analyzed proliferation or activation markers (Figure 3E). This was not due to downregulation of these markers that might be potentially induced by the isolation procedure, in control experiments where $\mathrm{T}$ cells expressing these markers there was no downregulation of their expression following the isolation procedure (Supplementary Figures 5A,B). In agreement with $\mathrm{T}_{\mathrm{RM}}$ features described from other tissues $(3,7), \mathrm{CD}^{+} 9^{+}$skin $\mathrm{T}$ cells significantly downregulated CCR7 both in frequency (Figure 3F) and expression levels (Figures 3G,H), in comparison with their $\mathrm{CD}^{-} 9^{-}$counterparts in the skin (Figures 3F,G) or paired blood (Figure 3H). Together, these results describe a steady-state, memory $\mathrm{T}$ cell population as resident in the normal human adult skin. Furthermore, they demonstrate that the optimized M.CoIV_6 $\mathrm{h}$ isolation protocol does not activate skin T cells.

\section{Various Types of Antigen-Presenting Cells Can Be Isolated From the Human Skin by the M.ColV Protocol}

APCs mediate cellular immune responses by processing and presenting antigens for the recognition by $\mathrm{T}$ cells. We next analyzed whether the M.CoIV_6h protocol enables the isolation of major types of human skin APCs. The following five major described types of APCs in the human skin (24) were characterized, namely, (1) plasmacytoid dendritic cells (pDCs), (2) conventional dendritic cells (cDCs), (3) $\mathrm{CD}_{1} 4^{+}$dermal dendritic cells (CD14 ${ }^{+}$DDCs), (4) $\mathrm{CD}^{+}{ }^{+}$dermal dendritic cells (CD1a ${ }^{+}$DDCs), and (5) Langerhans cells (LCs) (Figures 4A,B). Among ex vivo lineage negative human skin lymphocytes (CD45 ${ }^{+} \mathrm{HLA}-$ $\left.\mathrm{DR}^{+} \mathrm{DUMP}^{-}\right), \mathrm{pDCs}$ were rare while $\mathrm{cDCs}$ were relatively abundant ( 0.27 vs. $11.75 \%)$, which is consistent with previous findings $(22,23)$, that the low levels of CD303 expression by skin $\mathrm{pDCs}$ were not due to the downregulation that might be potentially induced by the isolation procedure (Supplementary Figures 5C,D). Additionally, CD1a ${ }^{+} \mathrm{DDCs}$
(37.91\%), CD14 ${ }^{+}$DDCs (3.00\%), and LCs (5.00\%) could also be identified (Figure 4C). Thus, the M.CoIV_6h protocol is capable of effectively isolating various types of APCs from human skin tissues.

\section{Ex vivo Skin T Cells Exhibit Functional Capacities}

To validate whether memory $\mathrm{T}$ cells isolated from human skin are functional, cytokine profiles of cells upon ex vivo antigenic stimulation were evaluated in comparison with paired blood memory $\mathrm{T}$ cells (Supplementary Figure 6). Skin and blood mononuclear cells were stimulated with the super antigen SEB and CD28 antibodies for $7 \mathrm{~h}$. Memory CD4 ${ }^{+}$ $\mathrm{T}$ cells reacting to the antigen were identified according to the expression of $\operatorname{CD} 154(25,26)$ and one or more of the cytokines TNF- $\alpha$, IFN- $\gamma$, IL-2, or IL-17 as assessed by intracellular immunolfluorescence (7). T cells that have two or more functions, such as the production of cytokines, are polyfunctional. Polyfunctionality of $\mathrm{T}$ cells is associated with enhanced protection (27). In response to the stimulation with SEB, CD $154^{+}$cytokine $^{+}$cells were readily detectable both in blood and skin with comparable frequencies (Figure 5A) and absolute cell numbers (data not shown). Among four matched samples, the fraction of polyfunctional cytokine-producing (polyCyt ${ }^{+}$) $\mathrm{T}$ cells were higher in memory $\mathrm{CD}^{+} \mathrm{T}$ cells from skin than blood (Figure 5B). Likewise, higher frequencies of polyCyt $^{+}$memory $\mathrm{CD}^{+} \mathrm{T}$ cells were found from skin than blood in three out of four donors (Figure 5B). In terms of the expression of IL-17A, both skin $\mathrm{CD}^{+}$and $\mathrm{CD}^{+} \mathrm{T}$ cells secreted more $\mathrm{IL}-17^{+} \mathrm{CD} 154^{+}$cells than their blood-derived counterparts in two analyzed donors (Figure 5C). In addition, on average about $30 \%$ of skin memory $\mathrm{T}$ cells responded to the stimulation with anti-CD3 and anti-CD28 (Figure 5D, Supplementary Figure 7).

Finally we evaluated whether memory $\mathrm{T}$ cells isolated from human skin could be used for antigen-specific responses and other parameters that may require longer periods of time in ex vivo cultures. To this end, skin cells were isolated using the optimized M.CoIV_6 $\mathrm{h}$ protocol and further examined after 5-day ex vivo cultures for their viability and proliferation potential. When cultured in medium alone, the number of skin $\mathrm{T}$ cells on day 5 remained similar to that of day 0 (data not shown). Of note, when cultured in medium supplemented with IL-2, about $30 \%$ of skin $\mathrm{T}$ cells had proliferated (Figure 6A) on day 5, that more than $70 \%$ of proliferation was observed in cultures in the presence of additional anti-CD3 and anti-CD28 (Figure 6B). Together, these results demonstrate that expanded skin $(\mathrm{T})$ cells can be used for further downstream applications. 


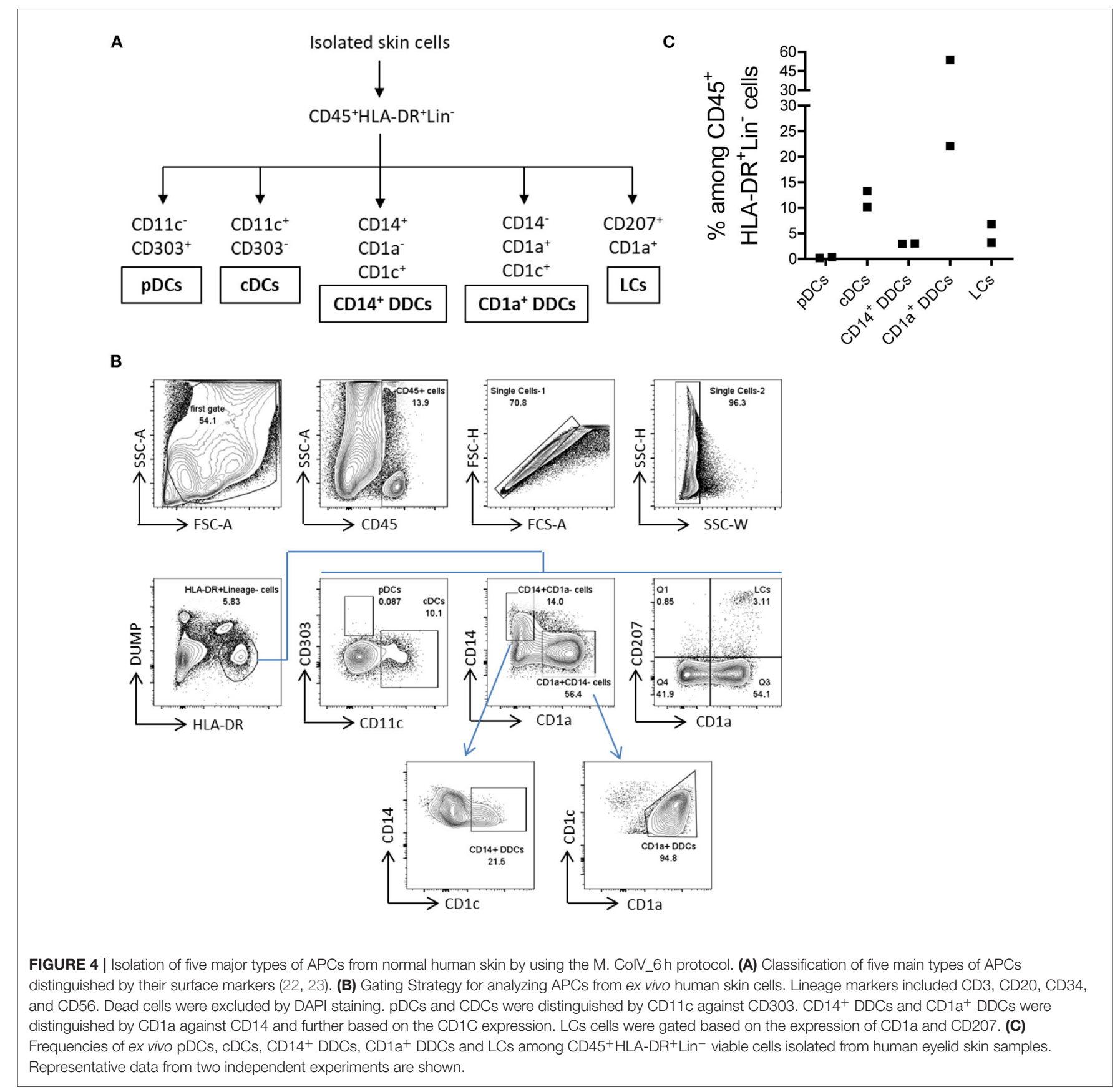

\section{DISCUSSION}

We report in this study optimization of rapid and efficient isolation protocols for characterizing human skin $\mathrm{T}_{\mathrm{RM}}$ cells, in comparison with their matched blood counterparts. To date, human cutaneous $\alpha \beta^{+} \mathrm{T}$ cells in situ have been characterized mostly by immunohistochemistry staining $(19,28$, 29), which might be biased either by the reaction itself or by incorrect interpretation (30). In the present report, by applying immunofluorescence staining techniques, we showed that $\mathrm{CD} 4^{+}$ and $\mathrm{CD}^{+} \mathrm{T}$ cells can be detected both in the epidermis and dermis, with $\mathrm{CD} 4^{+} \mathrm{T}$ cells predominantly detected in the dermis (especially clustered around hair follicles). Our findings are supported by other studies (31-33) describing the $\mathrm{T}_{\mathrm{RM}}$ cell tropism to the epidermis and follicles as epidermotropism. Studies in animal models showing that the preferential location of $\mathrm{CD}^{+}$and $\mathrm{CD} 8^{+} \mathrm{T}_{\mathrm{RM}}$ cells in skin demonstrate their immediate local immune surveillance and protective responses at the site of antigen exposure $(1,2,17,34)$. The loose spatial structure of the dermis shaped by an abundant extracellular matrix may facilitate the interaction between $\mathrm{CD} 4^{+} \mathrm{T}$ helper cells with other immune cells and non-immune components, e.g., hair follicles 

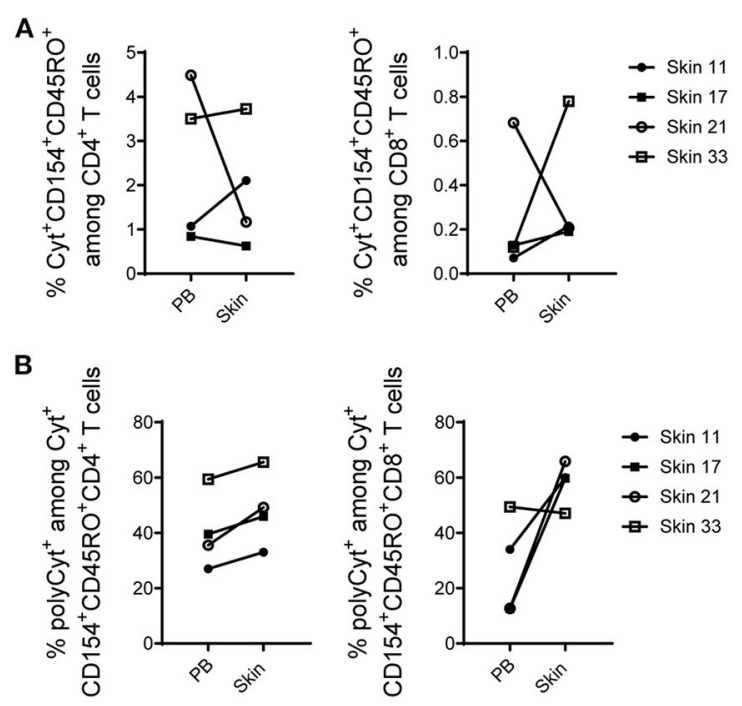

C

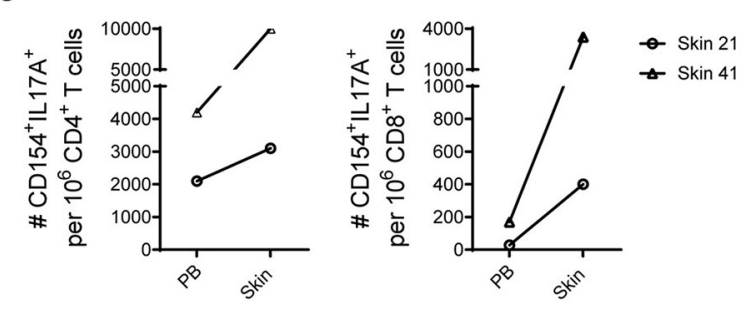

D

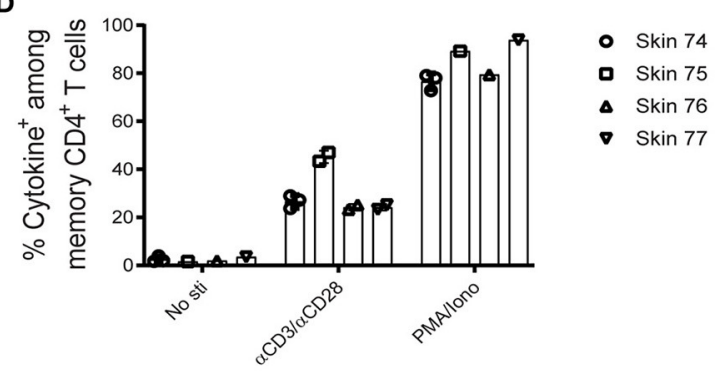

FIGURE 5 | Functional capacities of T cells from skin and paired peripheral blood samples. (A-C), mononuclear cells isolated from five paired skin and PB samples were stimulated with the SEB, and the induced cytokine production (IFN- $\gamma$, IL-2, or TNF- $\alpha$; alternatively IFN- $\gamma, \mathrm{IL}-2$, TNF- $\alpha$, or IL-17A) in memory $\mathrm{CD}^{+}$and $\mathrm{CD}^{+}{ }^{+} \mathrm{T}$ cells was examined according to CD154 expression. For each subpopulation, the background (as detected in the anti-CD28 stimulated but otherwise equally treated control samples) was subtracted. (A) Antigen-specific CD154 ${ }^{+}$cytokine ${ }^{+}$(total cytokine-producing) memory CD4 ${ }^{+}$ and $\mathrm{CD}^{+} \mathrm{T}$ cells are shown in frequencies among $\mathrm{CD} 4^{+}$and $\mathrm{CD} 8^{+} \mathrm{T}$ cells. (B) The proportions of polyCyt ${ }^{+}$-producing (more than one of the analyzed three or four cytokines TNF- $\alpha$, IFN- $\gamma$, IL-2, or IL-17A) memory T cells among cytokine ${ }^{+} \mathrm{CD} 154{ }^{+} \mathrm{CD} 45 \mathrm{RO}^{+} \mathrm{CD}^{+}$and $\mathrm{CD} 8^{+} \mathrm{T}$ cells. (C) The absolute numbers of $\mathrm{IL}-17 \mathrm{~A}^{+}$cells per million $\mathrm{CD}^{+}$and $\mathrm{CD}^{+}{ }^{+} \mathrm{T}$ cells isolated from two analyzed paired skin and blood samples upon SEB stimulation are shown. (D) Percentage of cytokine ${ }^{+}$cells among skin memory CD4 ${ }^{+} \mathrm{T}$ cells in response to $\alpha \mathrm{CD} 3 / \alpha \mathrm{CD} 28$ stimulation. No antigens and PMA/lonomycin stimulation were included as controls. Bars with two or three data points are shown as the mean of replicates of cells analyzed from each sample.

(35). Studies in mice have demonstrated that after HSV infection, memory $\mathrm{CD}^{+}{ }^{+} \mathrm{T}$ cells are recruited and formed clusters around hair follicles in a CCL5-dependent manner (32). Moreover, hair

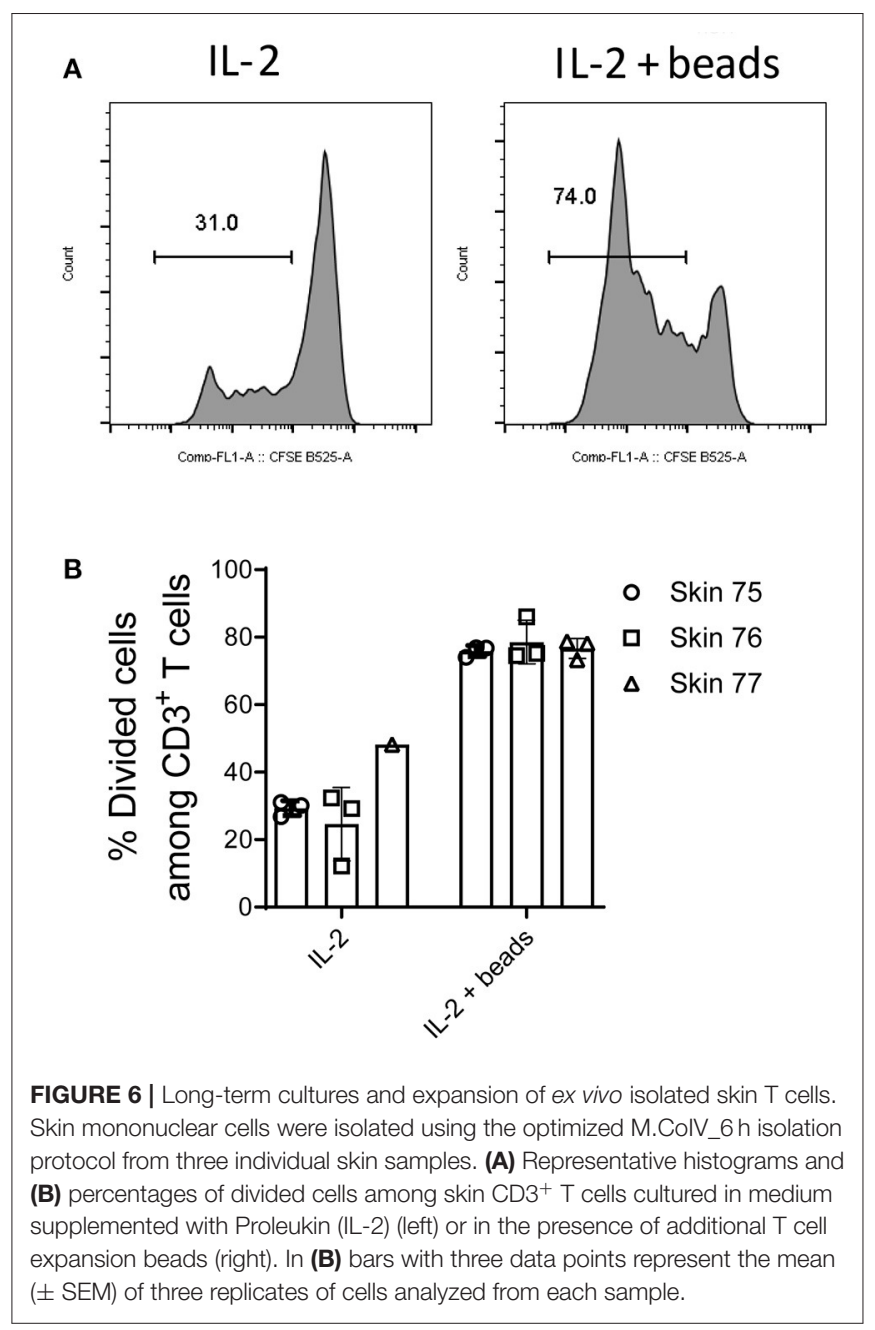

follicle keratinocyte-derived IL-15 has been described to be required for the maintenance of $\mathrm{CD}^{+} \mathrm{T}_{\mathrm{RM}}$ cells, and IL-7 for $\mathrm{CD}^{+}$and $\mathrm{CD}^{+} \mathrm{T}_{\mathrm{RM}}$ cells (31). Therefore, hair follicles may be a preferred site of pathogen exposure and thus, for locating $\mathrm{T}_{\mathrm{RM}}$ cells. On the other hand, our histological data also showed a close proximity of $\mathrm{CD}^{+} \mathrm{T}$ cells to $\mathrm{CD} 1 \mathrm{a}^{+} \mathrm{DCs}$, which may facilitate antigen presentation and provision of other survival signals by $\mathrm{CD}_{\mathrm{a}}{ }^{+} \mathrm{DCs}$ to $\mathrm{T}_{\mathrm{RM}}$ cells. Interestingly, only cells in the epidermis but not T cells express CCR7 and Ki-67, which is a feature of keratinocytes (36).

To study the human skin $\mathrm{T}_{\mathrm{RM}}$ cells, several isolation methods were reported $(20,21)$. However, these methods either suffer from low yield or require long-term in vitro culture periods. To overcome these challenges, here we have established an optimized protocol for rapidly isolating skin $\mathrm{T}_{\mathrm{RM}}$ cells by the combinatorial and sequential procedures of a short period of collagenase IV digestion and a gentle mechanical tissue dissociation. As the dermis has an abundant extracellular matrix comprised of collagen and elastin fibers (35), different types of collagenases [I (37), 1A (38), or IV (21)] alone or in combination have been applied to break down these extracellular structures. In particular, type IV collagenase has a lower tryptic activity and 
high collagenase activity, which limits the damage to membrane proteins and receptors while effectively breaking down the collagen-rich dermal tissues, resulting in the effective release of intact $\mathrm{T}_{\mathrm{RM}}$ cells for downstream isolation. However, isolation of skin T cells with collagenase IV (19) or enzyme alone $(20,21)$ is not effective in isolating large number of $\mathrm{T}$ cells. Indeed, among the six analyzed protocols, only the M.CoIV_6 h enabled a high yield of viable total mononuclear cells and $\mathrm{T}$ cells, on average $2.8 \times 10^{5}$ cells per $\mathrm{cm}^{2}$ of skin. Based on the reasonable estimate that the number of $\mathrm{T}$ cells in $1 \mathrm{~cm}^{2}$ of skin is $1.1 \times 10^{6}(19)$, we were able to isolate more than $20 \%$ of proportioned skin $\mathrm{T}$ cells, which is comparable with skin $\mathrm{T}$ cells isolated using the skin explant cultures (19). Additionally, although we observed slightly lower frequencies of $\mathrm{CCR}^{+}$ $\mathrm{T}$ cells from ex vivo than from in situ, it has been shown that neither collagenase digestion nor mechanical dissociation method modify the expressions of both CLA and chemokine receptors, such as the CCR4, CCR6, CCR8, and CCR10, on isolated ex vivo skin T cells (20). Thus, the M.CoIV_6h protocol should not alter features of skin T cells. In fact, the M.CoIV_6 h protocol also best preserved critical expressions of surface markers such as CD4, CD8, and CD69 on skin T cells. In line with their in situ status, isolated ex vivo skin $\mathrm{T}$ cells exhibit a memory phenotype, express the tissue-resident marker CD69 and the skin-homing receptor CLA but lack the expression of CCR7, Ki-67, and other putative activation markers, indicating their non-proliferating, inactive, and tissue resident status in the steady state.

In addition, using the M.CoIV_6h protocol, not only memory $\mathrm{T}$ cells but also major types of APCs could be effectively isolated from fresh human skin tissues, which allowed for a further assessment of the functionalities of skin $T$ cells. In line with our previous findings of preferential enrichment of polyfunctional memory $\mathrm{T}$ cells in the human bone marrow (7), polyfunctional memory $\mathrm{T}$ cells are also more frequent in the skin than blood. This observation suggests that there is a preferential location of memory $\mathrm{T}$ cells in the skin with distinct antigen exposure experience, such as to Candida albicans (39), as evidenced by their higher amount of IL-17 production. The ex vivo skin $\mathrm{T}$ cell responses are likely an attribute of the effective isolation of various types of APCs. Thus, this optimized protocol could help pave the way for research in human skin $\mathrm{T}_{\mathrm{RM}}$ cells as such and, in particular, in direct comparison with their blood-circulating counterparts at the same sampling time.

\section{MATERIALS AND METHODS}

\section{Study Cohort}

This study was approved by the ethics committee at the Charité - Universitätsmedizin Berlin, Germany (EA1/290/14). All blood and skin tissue samples were obtained with informed consent from all donors. Samples taken from normal adult skin with paired peripheral blood samples (mean age \pm SEM, $67.29 \pm 3.55 y ; n=14$ ) or without (mean age \pm SEM, $58.42 \pm 2.90 y ; n=24$ ) were obtained from healthy donors undergoing plastic cutaneous surgeries (Supplementary Table 1).

\section{Histological Staining}

Skin samples were immediately fixed in $2 \%$ paraformaldehyde (Carl Roth) for $4 \mathrm{~h}$ at $4^{\circ} \mathrm{C}$. Following fixation, samples were sequentially equilibrated in solutions supplemented with 10$30 \%$ sucrose (Carl Roth), each for $24 \mathrm{~h}$ at $4^{\circ} \mathrm{C}$. Samples were then embedded in O.C.T ${ }^{\mathrm{TM}}$ media (SAKURA) and stored at $-80^{\circ} \mathrm{C}$ until cryosectioning using Kawamoto's tape method (40) with a microtome MH560 cryostat (Thermo Fisher). Tissue sections in $6 \mu \mathrm{m}$ were blocked with blocking buffer (PBS with $0.1 \%$ Tween 20, and $10 \%$ FCS) for $1 \mathrm{~h}$ at room temperature and then stained with primary and secondary antibodies as well as DAPI $(2 \mu \mathrm{g} / \mathrm{mL})$ to label cell nuclei. Among the used anti-human antibodies, anti-CD3 Alexa Fluor 594 (UCHT1), anti-CD4 Alexa Fluor 555 (TT1), anti-CD8 Alexa Fluor 647 (GN11/134D7), anti-CD1a Cy5 (OKT6) were conjugated in house. Other antibodies include anti-CD69 Alexa Fluor 488 (FN50; Biolegend), anti-CCR7 Alexa Fluor 555 (Y59; Abcam), Anti- Ki-67 Biotin (SolA15; eBioscience), antiCLA APC (HECA-452; Miltenyi) and streptavidin Alexa Fluor 488 (Thermofischer).

Following staining, the sections were mounted with fluorescent mounting medium (DAKO). Confocal images were generated using a Zeiss LSM710 (Carl Zeiss). Skin section picture composites were generated by three-dimensional tile scanning using a Plan-Apochromat 20X (0.8 numerical aperture; NA) air objective lens. The displayed overview image was part of $3 \times 4$ tile scans, with maximum intensity projections of $\mathrm{z}$-stacks each with $1.3 \mu \mathrm{m}$ z-resolution and $\mathrm{x}-\mathrm{y}$ resolution of $7,578 \times 5,734$ pixels. Tiles were recorded with a $10 \%$ overlap and projections stitched together by the acquisition software to generate three high-resolution images. Images were analyzed using the ZEN software (blue edition).

For quantification of cells, the segmentation pipeline was designed using a previously described similar approach (41) and performed in Fiji, a distribution of ImageJ/Fiji (1.52p) (42). In every image set nuclei were identified by a plugin called "StarDist" (43). The objects were further used to measure the nuclear area and mean intensity in every staining. Signals above defined intensity thresholds were counted as positive signals. Counting of co-expressing cells was performed by using multiple thresholds for the markers of interest.

\section{Skin and Blood Sample Preparation}

Peripheral blood mononuclear cells (PBMCs) were isolated by density gradient sedimentation using Ficoll-Paque ${ }^{\mathrm{TM}}$ Plus (Sigma-Aldrich). Skin samples were delivered in CUSTODIOL ${ }^{\circledR}$ HTK solution (kindly provided by the Köhler Chemie, Germany) for $<24 \mathrm{~h}$ until further preparation. In brief, skin samples were rinsed with cold PBS buffer, and the subcutaneous fat and hairs were carefully removed. Skin tissues were minced with sterile scissors into $2-4 \mathrm{~mm}$ fragments. About 25-50 fragments were digested in $3 \mathrm{~mL}$ digestion media in an incubator at $37^{\circ} \mathrm{C}$ and $5 \% \quad \mathrm{CO}_{2}$. Various components 
were used to digest skin fragments in different protocols (Supplementary Table 2), such as $0.8 \mathrm{mg} / \mathrm{mL}$ collagenase IV (Worthington), $0.4 \mathrm{mg} / \mathrm{mL}$ collagenase $\mathrm{P}$ (Roche), 1.25 $\mathrm{mg} / \mathrm{mL}$ collagenase I (Sigma-Aldrich), $0.5 \mathrm{mg} / \mathrm{mL}$ elastase (Worthington), $0.5 \mathrm{mg} / \mathrm{mL}$ hyaluronidase (Worthington), 0.02 or $0.1 \mathrm{mg} / \mathrm{mL}$ DNAse I (Roche), $0.1 \mathrm{mg} / \mathrm{mL}$ trypsin inhibitor (Sigma-Aldrich) and $3.2 \mathrm{~mm} \mathrm{CaCl} 2 \cdot 2 \mathrm{H}_{2} \mathrm{O}$. RPMI1640 or DMEM culture medium (Thermo Fisher) was supplemented with $5 \%$ human $\mathrm{AB}$ serum (Sigma-Aldrich), 1\% HEPES, 1\% Pen/Strep (100 U/mL penicillin; $100 \mu \mathrm{g} / \mathrm{mL}$ streptomycin). The digestion procedure was terminated by adding an equal volume of PBS consisting of $2 \mathrm{mM}$ EDTA. Skin fragments were then dissociated with a Gentle MACS Dissociator (Miltenyi Biotec). The homogenized tissue samples were further filtered through a $70 \mu \mathrm{m}$ cell strainer (Miltenyi Biotec). If present, residual fragments were dissociated through a second dissociation step. Upon isolation, viable cells were quantified with DAPI using a MACSQuant. Digestion procedures using the whole skin dissociation kit with or without enzyme $\mathrm{P}$ (WSD+/-EnzP) (Miltenyi Biotec) were performed according to manufacturer's recommendation.

\section{Ex vivo Antigen Stimulation}

Isolated mononuclear cells from the blood and skin were adjusted to a density of $1 \times 10^{7}$ cells $/ \mathrm{mL}$ in culture medium. Cells were stimulated with $1 \mu \mathrm{g} / \mathrm{mL}$ Staphylococcus Enterotoxin B (SEB) (Sigma-Aldrich), plate bound $\alpha \mathrm{CD} 3 / \alpha \mathrm{CD} 28$ (Thermo Fischer; each $1 \mu \mathrm{g} / \mathrm{mL}$ ) or PMA $(1 \mathrm{ng} / \mathrm{mL})$ plus Ionomycin $\left(1 \mu \mathrm{g} / \mathrm{mL}\right.$ ) (Thermo Fischer) for $7 \mathrm{~h}$ at $37^{\circ} \mathrm{C}, 5 \%$ $\mathrm{CO}_{2}$, with $5 \mu \mathrm{g} / \mathrm{mL}$ Brefeldin A (Biolegend) added during the last $2 \mathrm{~h}$. Cultured cells without added antigen served as negative controls.

\section{Cell Surface and Intracellular Staining for Flow Cytometry Analysis}

Up to 10 million cells were stained with antibodies and Fc Blocking reagent (Miltenyi Biotec) for $10 \mathrm{~min}$ in the dark at $4^{\circ} \mathrm{C}$. When staining with the anti-CCR7 antibody, cells were stained for $15 \mathrm{~min}$ in the dark at $37^{\circ} \mathrm{C}$. To detect the intracellular production of cytokines, stimulated cells were fixed with $2 \%$ paraformaldehyde followed by permeabilization (Perm 2; BD Biosciences), prior to intracellular CD154 and cytokine staining. The following fluorochrome-conjugated mouse antihuman antibodies were used to stain cells: anti-CD45 PEvio770 (5B1), anti-CD45 APC-vio770 (5B1), anti-CLA APC (HECA-452), anti-CD25 APC (REA570), anti-CD11c Percpvio770 (MJ4-27G12), anti-CD207 Pe-vio770 (MB22-9F5) and anti-CD1c FITC (AD5-8E7) (Miltenyi Biotec), anti-CD45 BV785 (HI30), anti-CD3 A700 (HIT3a), anti-CD8 BV785 (RPA-T8), anti-CD69 BV421 (FN50), anti-CD154 BV421 (24-31), antiHLA-DR APC-Cy7 (L243), anti-CD45RO BV650 (UCHL1), anti-CCR7 A488 (G043H7), CD20 BV510 (2H7), CD34 BV510 (581), CD56 BV510 (HCD56), CD14 BV605 (M5E2), CD303 BV421 (201A), IL-2 FITC (MQ1-17H12), and IFN- $\gamma$ PE-Cy7 (B27) (Biolegend), anti-CD3 APC-H7 (Sk7), anti-CD3 V500 (UCHT-1), anti-CD19 V500 (HIB19), CD141 BV711 (1A4) and TNF APC (MAb11) (BD Biosciences), anti-CD4 Pe-Cy5.5 (Sk3), anti-Ki-67 PE (20Raj1), anti-CD137 FITC (4B4) and IL-17 PE (eBio64DEC17) (eBioscience), and anti-CD14 Pacific Orange (TM1), anti-CD19 Pacific Orange (BU12) and CD1a Cy5 (OKT6) (house conjugate). Stained cells were acquired using a MACSQuant (Miltenyi Biotec) or a LSRFortessa (BD Biosciences) flow cytometer. At least $1 \times 10^{6}$ lymphocytes were acquired. The data were analyzed with Flowjo V10 (Tree Star).

\section{CFSE Labeling and Long-Term Cell Culture}

Freshly isolated skin mononuclear cells using the M.CoIV_6h isolation protocol were labeled with Carboxyfluorescein succinimidyl ester (CFSE) at the final concentration of $2.5 \mu \mathrm{M}$. Briefly, cells were washed twice in PBS and the cell pellet was resuspended in PBS at density of $10 \times 10^{6}$ cells $/ \mathrm{mL}$, and then labeled with $2.5 \mu \mathrm{M}$ CFSE at $37^{\circ} \mathrm{C}$ for $10 \mathrm{~min}$. The reaction was stopped by adding $5 \mathrm{~mL}$ FCS and washed twice. Labeled skin cells were cultured in X-vivo 15 medium (Lonza) containing 10\% human $\mathrm{AB}$ serum and $500 \mathrm{IU} / \mathrm{mL}$ Proleukin (IL-2; Novartis) as well as $1 \%$ Pen/Strep for 5 days. Fractions of skin cells were additionally stimulated with $\mathrm{T}$ activation/expansion beads (Miltenyi Biotec) at a bead-to-cell ratio of $1: 1$.

\section{Statistics}

Statistical analyses were performed with Graphpad Prism software (version 5.04). For analysis of two groups, two-tailed Wilcoxon matched-pairs signed rank test or unpaired $T$-test with Welch's correction was used, and a $p$-value under 0.05 was considered statistically significant.

\section{DATA AVAILABILITY STATEMENT}

The raw data supporting the conclusions of this article will be made available by the authors, without undue reservation.

\section{ETHICS STATEMENT}

The studies involving human participants were reviewed and approved by the ethics committee at the Charité University Medicine, Berlin, Germany (EA1/290/14). The patients/participants provided their written informed consent to participate in this study.

\section{AUTHOR CONTRIBUTIONS}

JD: conceptualization, writing - review \& editing, supervision, and project administration. WD, DL, RK, AEH, and JD: methodology. EZ, JW, and JB: sample resource. WD: investigation and writing - original draft. WD, RK, CC, JL, and MM: analysis. WD and JD interpretation. JD and $\mathrm{AR}$ funding acquisition. All authors contributed to the article and approved the submitted version. 


\section{FUNDING}

This work was supported by the Deutsche Forschungsgemeinschft (DFG, German Research Foundation) - Projektnummer 389687267 awarded to JD and AR and by the European Research Council (ERC) Advanced Grant 268987 awarded to AR. WD was supported in part by the China Scholarship Council (CSC). CC was supported in part by the Leibniz Graduate School for Rheumatology (LGRh). AH was supported by a grant from the DFG (HA5354/8-2), within the SPP1937.

\section{REFERENCES}

1. Clark RA, Watanabe R, Teague JE, Schlapbach C, Tawa MC, Adams N, et al. Skin effector memory $\mathrm{T}$ cells do not recirculate and provide immune protection in alemtuzumab-treated CTCL patients. Sci Transl Med. (2012) 4:117ra7. doi: 10.1126/scitranslmed.3003008

2. Gebhardt T, Wakim LM, Eidsmo L, Reading PC, Heath WR, Carbone FR. Memory T cells in nonlymphoid tissue that provide enhanced local immunity during infection with herpes simplex virus. Nat Immunol. (2009) 10:52430. doi: 10.1038/ni.1718

3. Kumar BV, Ma W, Miron M, Granot T, Guyer RS, Carpenter DJ, et al. Human tissue-resident memory $\mathrm{T}$ cells are defined by core transcriptional and functional signatures in lymphoid and mucosal sites. Cell Rep. (2017) 20:2921-34. doi: 10.1016/j.celrep.2017.08.078

4. Purwar R, Campbell J, Murphy G, Richards WG, Clark RA, Kupper TS. Resident memory $\mathrm{T}$ cells $(\mathrm{T}(\mathrm{RM})$ ) are abundant in human lung: diversity, function, and antigen specificity. PLoS ONE. (2011) 6:e16245. doi: 10.1371/journal.pone.0016245

5. Stelma F, de Niet A, Sinnige MJ, van Dort KA, van Gisbergen K, Verheij J, et al. Human intrahepatic CD69 + CD8 + T cells have a tissue resident memory T cell phenotype with reduced cytolytic capacity. Sci Rep. (2017) 7:6172. doi: 10.1038/s41598-017-06352-3

6. Chang HD, Tokoyoda K, Radbruch A. Immunological memories of the bone marrow. Immunol Rev. (2018) 283:86-98. doi: 10.1111/imr. 12656

7. Okhrimenko A, Grun JR, Westendorf K, Fang Z, Reinke S, von Roth P, et al. Human memory $\mathrm{T}$ cells from the bone marrow are resting and maintain long-lasting systemic memory. Proc Natl Acad Sci USA. (2014) 111:922934. doi: 10.1073/pnas.1318731111

8. Sercan Alp Ö, Durlanik S, Schulz D, McGrath M, Grün JR, Bardua M, et al. Memory CD8 $+\mathrm{T}$ cells colocalize with IL-7+ stromal cells in bone marrow and rest in terms of proliferation and transcription. Eur J Immunol. (2015) 45:975-87. doi: 10.1002/eji.201445295

9. Siracusa F, Alp OS, Maschmeyer P, McGrath M, Mashreghi MF, Hojyo S, et al. Maintenance of CD8(+) memory T lymphocytes in the spleen but not in the bone marrow is dependent on proliferation. Eur J Immunol. (2017) 47:1900-5. doi: 10.1002/eji.201747063

10. Siracusa F, Durek P, McGrath MA, Sercan-Alp O, Rao A, Du W, et al. CD69(+) memory $\mathrm{T}$ lymphocytes of the bone marrow and spleen express the signature transcripts of tissue-resident memory T lymphocytes. Eur $J$ Immunol. (2019) 49:966-8. doi: 10.1002/eji.201847982

11. Farber DL, Yudanin NA, Restifo NP. Human memory T cells: generation, compartmentalization and homeostasis. Nat Rev Immunol. (2014) 14:2435. doi: $10.1038 /$ nri3567

12. Mackay LK, Rahimpour A, Ma JZ, Collins N, Stock AT, Hafon ML, et al. The developmental pathway for CD103(+)CD8+ tissue-resident memory T cells of skin. Nat Immunol. (2013) 14:1294-301. doi: 10.1038/ni.2744

13. Steinert EM, Schenkel JM, Fraser KA, Beura LK, Manlove LS, Igyarto $\mathrm{BZ}$, et al. Quantifying memory CD8 T cells reveals regionalization of immunosurveillance. Cell. (2015) 161:737-49. doi: 10.1016/j.cell.2015. 03.031

\section{ACKNOWLEDGMENTS}

We acknowledge the professional assistance of the Flow Cytometry Core Facility at Deutsches RheumaForschungszentrum Berlin. Thanks to Florenz Cruz for proofreading of the manuscript.

\section{SUPPLEMENTARY MATERIAL}

The Supplementary Material for this article can be found online at: https://www.frontiersin.org/articles/10.3389/fimmu. 2021.624013/full\#supplementary-material

14. Feng C, Woodside KJ, Vance BA, El-Khoury D, Canelles M, Lee J, et al. A potential role for CD69 in thymocyte emigration. Int Immunol. (2002) 14:535-44. doi: 10.1093/intimm/dxf020

15. Shiow LR, Rosen DB, Brdickova N, Xu Y, An J, Lanier LL, et al. CD69 acts downstream of interferon-[alpha]/[beta] to inhibit S1P1 and lymphocyte egress from lymphoid organs. Nature. (2006) 440:540-4. doi: 10.1038/nature 04606

16. Shinoda K, Tokoyoda K, Hanazawa A, Hayashizaki K, Zehentmeier S, Hosokawa $\mathrm{H}$, et al. Type II membrane protein CD69 regulates the formation of resting T-helper memory. Proc Natl Acad Sci USA. (2012) 109:740914. doi: 10.1073/pnas.1118539109

17. Jiang X, Clark RA, Liu L, Wagers AJ, Fuhlbrigge RC, Kupper TS. Skin infection generates non-migratory memory $\mathrm{CD} 8+\mathrm{T}(\mathrm{RM})$ cells providing global skin immunity. Nature. (2012) 483:227-31. doi: 10.1038/nature10851

18. Watanabe R, Gehad A, Yang C, Scott LL, Teague JE, Schlapbach C, et al. Human skin is protected by four functionally and phenotypically discrete populations of resident and recirculating memory T cells. Sci Transl Med. (2015) 7:279ra39. doi: 10.1126/scitranslmed.3010302

19. Clark RA, Chong B, Mirchandani N, Brinster NK, Yamanaka K, Dowgiert $\mathrm{RK}$, et al. The vast majority of CLA $+\mathrm{T}$ cells are resident in normal skin. $J$ Immunol. (2006) 176:4431-9. doi: 10.4049/jimmunol.176.7.4431

20. Salimi M, Subramaniam S, Selvakumar T, Wang X, Zemenides S, Johnson D, et al. Enhanced isolation of lymphoid cells from human skin. Clin Exp Dermatol. (2016) 41:552-6. doi: 10.1111/ced.12802

21. Sanchez Rodriguez R, Pauli ML, Neuhaus IM, Yu SS, Arron ST, Harris HW, et al. Memory regulatory T cells reside in human skin. J Clin Invest. (2014) 124:1027-36. doi: 10.1172/JCI72932

22. van de Ven R, van den Hout MF, Lindenberg JJ, Sluijter BJ, van Leeuwen PA, Lougheed SM, et al. Characterization of four conventional dendritic cell subsets in human skin-draining lymph nodes in relation to T-cell activation. Blood. (2011) 118:2502-10. doi: 10.1182/blood-2011-03-344838

23. Ju X, Clark G, Hart DN. Review of human DC subtypes. Methods Mol Biol. (2010) 595:3-20. doi: 10.1007/978-1-60761-421-0_1

24. Harman AN, Bye CR, Nasr N, Sandgren KJ, Kim M, Mercier SK, et al. Identification of lineage relationships and novel markers of blood and skin human dendritic cells. J Immunol. (2013) 190:6679. doi: 10.4049/jimmunol.1200779

25. Frentsch M, Arbach O, Kirchhoff D, Moewes B, Worm M, Rothe M, et al. Direct access to CD4+ $\mathrm{T}$ cells specific for defined antigens according to CD154 expression. Nat Med. (2005) 11:1118-24. doi: 10.1038/nm1292

26. Chattopadhyay PK, Yu J, Roederer M. A live-cell assay to detect antigenspecific CD4+ T cells with diverse cytokine profiles. Nat Med. (2005) 11:11137. doi: $10.1038 / \mathrm{nm} 1293$

27. Seder RA, Darrah PA, Roederer M. T-cell quality in memory and protection: implications for vaccine design. Nat Rev Immunol. (2008) 8:24758. doi: $10.1038 /$ nri2274

28. Wenzel J, Uerlich M, Worrenkamper E, Freutel S, Bieber T, Tuting T. Scarring skin lesions of discoid lupus erythematosus are characterized by high numbers of skin-homing cytotoxic lymphocytes associated with strong expression of the type I interferon-induced protein MxA. Br J Dermatol. (2005) 153:10115. doi: 10.1111/j.1365-2133.2005.06784.x 
29. Hemmerling J, Wegner-Kops J, von Stebut E, Wolff D, Wagner EM, Hartwig UF, et al. Human epidermal Langerhans cells replenish skin xenografts and are depleted by alloreactive T cells in vivo. J Immunol. (2011) 187:11429. doi: 10.4049/jimmunol.1001491

30. Matos LL, Trufelli DC, de Matos MG, da Silva Pinhal MA. Immunohistochemistry as an important tool in biomarkers detection and clinical practice. Biomark Insights. (2010) 5:9-20. doi: 10.4137/BMI.S2185

31. Adachi T, Kobayashi T, Sugihara E, Yamada T, Ikuta K, Pittaluga S, et al. Hair follicle-derived IL-7 and IL-15 mediate skin-resident memory $\mathrm{T}$ cell homeostasis and lymphoma. Nat Med. (2015) 21:12729. doi: $10.1038 / \mathrm{nm} .3962$

32. Collins N, Jiang X, Zaid A, Macleod BL, Li J, Park CO, et al. Skin CD4(+) memory $\mathrm{T}$ cells exhibit combined cluster-mediated retention and equilibration with the circulation. Nat Commun. (2016) 7:11514. doi: 10.1038/ncomms11514

33. Gebhardt T, Whitney PG, Zaid A, Mackay LK, Brooks AG, Heath WR, et al. Different patterns of peripheral migration by memory CD4+ and CD8+ T cells. Nature. (2011) 477:216-9. doi: 10.1038/nature10339

34. Gebhardt T, Mackay LK. Local immunity by tissue-resident Cd8+ memory T cells. Front Immunol. (2012) 3:340. doi: 10.3389/fimmu.2012.00340

35. Kabashima K, Honda T, Ginhoux F, Egawa G. The immunological anatomy of the skin. Nat Rev Immunol. (2019) 19:19-30. doi: 10.1038/s41577-018-0084-5

36. Nickoloff BJ, Griffiths CE. Intraepidermal but not dermal T lymphocytes are positive for a cell-cycle-associated antigen (Ki-67) in mycosis fungoides. Am J Pathol. (1990) 136:261-6.

37. He X, de Oliveira VL, Keijsers R, Joosten I, Koenen HJ. Lymphocyte isolation from human skin for phenotypic analysis and ex vivo cell culture. J Vis Exp. (2016) 110:e52564. doi: 10.3791/52564

38. Novelli M, Savoia P, Cambieri I, Ponti R, Comessatti A, Lisa F, et al. Collagenase digestion and mechanical disaggregation as a method to extract and immunophenotype tumour lymphocytes in cutaneous T-cell lymphomas. Clin Exp Dermatol. (2000) 25:423-31. doi: 10.1046/j.1365-2230.2000.00680.x

39. Gaffen SL, Hernandez-Santos N, Peterson AC. IL-17 signaling in host defense against Candida albicans. Immunol Res. (2011) 50:181-7. doi: 10.1007/s12026-011-8226-x

40. Kawamoto T. Use of a new adhesive film for the preparation of multi-purpose fresh-frozen sections from hard tissues, whole-animals, insects and plants. Arch Histol Cytol. (2003) 66:123-43. doi: 10.1679/aohc.66.123

41. Holzwarth K, Kohler R, Philipsen L, Tokoyoda K, Ladyhina V, Wahlby $\mathrm{C}$, et al. Multiplexed fluorescence microscopy reveals heterogeneity among stromal cells in mouse bone marrow sections. Cytometry A. (2018) 93:87688. doi: $10.1002 /$ cyto.a. 23526

42. Schindelin J, Arganda-Carreras I, Frise E, Kaynig V, Longair M, Pietzsch T, et al. Fiji: an open-source platform for biological-image analysis. Nat Methods. (2012) 9:676-82. doi: 10.1038/nmeth.2019

43. Weigert M, Schmidt U, Boothe T, Muller A, Dibrov A, Jain A, et al. Contentaware image restoration: pushing the limits of fluorescence microscopy. Nat Methods. (2018) 15:1090-7. doi: 10.1038/s41592-018-0216-7

Conflict of Interest: The authors declare that the research was conducted in the absence of any commercial or financial relationships that could be construed as a potential conflict of interest.

Copyright (C) 2021 Du, Lenz, Köhler, Zhang, Cendon, Li, Massoud, Wachtlin, Bodo, Hauser, Radbruch and Dong. This is an open-access article distributed under the terms of the Creative Commons Attribution License (CC BY). The use, distribution or reproduction in other forums is permitted, provided the original author(s) and the copyright owner(s) are credited and that the original publication in this journal is cited, in accordance with accepted academic practice. No use, distribution or reproduction is permitted which does not comply with these terms. 